\title{
Selenomonas lipolytica sp. nov., an obligately anaerobic bacterium possessing lipolytic activity
}

\author{
Abhijit S. Dighe, ${ }^{1}$ Yogesh S. Shouche ${ }^{2}$ and Dilip R. Ranade ${ }^{1}$
}

Author for correspondence: Dilip R. Ranade.e-mail : drr@aripune.ernet.in

1 Division of Microbial Sciences, Agharkar Research Institute, G. G. Agarkar Road, Pune 411 004, India

2 National Centre for Cell Science, Pune University Campus, Ganesh Khind, Pune 411 007, India

\begin{abstract}
A novel, obligately anaerobic bacterium capable of hydrolysing lipids was isolated from a tropical anaerobic lagoon receiving waste water from an edible oil mill. The isolate had many characteristics similar to those of members of the genus Selenomonas. The isolate showed lipolytic activity on tributyrin, triolein and groundnut oil in qualitative plate clearance assays, which has not been reported for the type strain of the genus Selenomonas. It did not require n-valerate supplementation for growth on glucose. Acetate and propionate were the only volatile fatty acids produced from glucose fermentation with propionate as the major end product. The isolate could grow optimally at pH 6.8 and at a temperature of $40{ }^{\circ} \mathrm{C}$. It could tolerate $\mathrm{NaCl}$ concentrations of up to $40 \mathrm{~g} \mathrm{I}^{-1}$. The $\mathrm{G}+\mathrm{C}$ content of the DNA was $40 \mathrm{~mol} \%$ as determined by thermal denaturation analysis. Comparison of partial 165 rRNA gene sequences revealed that the isolate was most closely related to genus Selenomonas with $91 \%$ sequence similarity ( 250 bp compared) to Selenomonas ruminantium strain GA 192. On the basis of the results obtained in the present investigation, it is suggested that a new species of Selenomonas should be created for this novel isolate and the name Selenomonas lipolytica is proposed for this new species. The type strain is strain CF1B' (= MCMB 505').
\end{abstract}

Keywords: anaerobic bacterium, lipase, lipid degradation, Selenomonas lipolytica sp. nov.

\section{INTRODUCTION}

Amongst the various microbial extracellular enzymes with commercial applications, lipase is an important one. Lipase is used on a large scale in cheese production, detergent manufacture and organo-conversions. Micro-organisms producing lipase play a significant role in degradation of complex organic matter containing lipid, both in the natural environment and in waste-treatment plants. These microorganisms are also said to be responsible for spoilage of pickles and vegetable oils (Sarnaik et al., 1989).

Different aerobic bacteria and fungi have been reported as lipase-producing microbes. Commercial

\footnotetext{
Abbreviations: PY, peptone/yeast extract medium; PYG, peptone/yeast extract/glucose medium; RDP, Ribosomal Database Project; $S_{a b}$, similarity value; $T_{m}$ midpoint of DNA melting temperature.

The GenBank accession number for the sequence reported in this paper is AF001901.
}

production of lipase relies solely on aerobic bacteria and fungi. Most of the knowledge about the biochemical nature of lipase and the process of lipolysis is also based on enzyme preparations obtained from aerobic organisms. Obligate anaerobes possessing lipolytic activity have received less attention. Much of the available information on lipid degradation under anaerobic conditions is in relation to activities in the rumen. Hobson \& Mann (1961) isolated a glycerolfermenting and lipolytic bacterium from the rumen of sheep. Later, Hungate (1966) designated this lipolytic strain, which could hydrolyse linseed oil triglycerides to glycerol and free fatty acids, Anaerovibrio lipolytica. Henderson (1971) studied the lipase produced by $A$. lipolytica and partially purified the enzyme. Schauder \& Schink (1989) described a new species of the genus Anaerovibrio as Anaerovibrio glycerini, which could ferment glycerol and glycerol residues of diolein. Four species of the genus Clostridium (Clostridium aurantibutyricum, Clostridium botulinum, Clostridium novyi and Clostridium sporogens) are reported to produce 
lipase, but very little is known about their actual lipolytic ability (Cato et al., 1986). Generally, there are hardly any other obligately anaerobic bacteria that have been isolated and identified which possess true lipolytic activity (P. N. Hobson, personal communication).

Nowadays, anaerobic bacteria and their activities are gaining importance. This is mainly due to the fact that these bacteria do not require aeration during growth and hence energy can be saved. Attempts have been made to express 'lipase' genes of aerobes when the culture is grown under $\mathrm{O}_{2}$-limited conditions, to save the cost of aeration and agitation. Winteler et al. (1996) tried to manipulate a strain of Pseudomonas aeruginosa (PAO 1) so that it could grow under anaerobic conditions (nitrate respiration or anaerobic fermentation using L-arginine) and would overproduce lipase.

Secondly, anaerobic bacteria, along with methanogens, bring about degradation of complex matter and simultaneously produce gaseous fuel in the form of methane. With this background, a search for anaerobes having extracellular enzymes is essential. In this report, one strain of an obligate anaerobe showing strong lipolytic activity was isolated and its properties were investigated.

\section{METHODS}

Bacterial strain. Strain CF1B ${ }^{T}$ was isolated from an anaerobic lagoon receiving waste-water from an edible oil mill near Pune, India. The in situ temperature of the lagoon was $33^{\circ} \mathrm{C}$ and the $\mathrm{pH}$ was 6.95 . A sample of semi-solid sediment was collected from the lagoon. During the collection and transport period of $2 \mathrm{~h}$, care was taken to maintain anoxic conditions.

Media and culture conditions. The solid and liquid media were prepared according to the anaerobic techniques described by Hungate (1969) and subsequently modified by Miller \& Wolin (1974).

The emulsions of groundnut oil, triolein and tributyrin were prepared in distilled water as well as in $2 \%(\mathrm{w} / \mathrm{v})$ polyvinyl alcohol solution in distilled water. The distilled water (or polyvinyl alcohol solution) was boiled and cooled to room temperature under a constant stream of $\mathrm{O}_{2}$-free $\mathrm{N}_{2}$ to expel all the dissolved $\mathrm{O}_{2}$. Cysteine. $\mathrm{HCl}\left(0.5 \mathrm{~g} \mathrm{t}^{-1}\right)$ was then added as the reducing agent in the distilled water. The $\mathrm{pH}$ of the distilled water was adjusted to $7 \cdot 0$ with $1 \mathrm{M} \mathrm{NaOH}$ solution. The substrate was mixed with anaerobic distilled water prepared as above to give final concentration of substrate of $200 \mathrm{~g} \mathrm{l}^{-1}$. It was then emulsified in an ultrasonicator until a milky white homogeneous emulsion was obtained. The emulsified solution was dispensed in $65 \mathrm{ml}$ capacity serum vials under a continuous passage of $\mathrm{O}_{2}$-free $\mathrm{N}_{2}$. The vials were sealed under $\mathrm{N}_{2}$ using butyl rubber stoppers and aluminium seals. The vials were sterilized by autoclaving at $121{ }^{\circ} \mathrm{C}$ for $30 \mathrm{~min}$.

The strain was enriched, subsequently isolated and maintained on nutrient medium, henceforth referred to as OA-1 medium, having the following composition $\left(1^{-1}\right): 0.3 \mathrm{~g}$ $\mathrm{KH}_{2} \mathrm{PO}_{4} ; 1.0 \mathrm{~g} \mathrm{NH}_{4} \mathrm{Cl} ; 0.6 \mathrm{~g} \mathrm{NaCl} ; 0.1 \mathrm{~g} \mathrm{MgCl}_{2} .6 \mathrm{H}_{2} \mathrm{O}$; $0.2 \mathrm{~g} \mathrm{CaCl}_{2}$ anhydrous; $5.0 \mathrm{~g}$ yeast extract; $5.0 \mathrm{~g}$ tryptone;
$1 \mathrm{ml}$ trace element solution (Touzel \& Albagnac, 1983); $1 \mathrm{ml}$ trace vitamin solution (Wolin et al., 1963); $1 \mathrm{ml}$ resazurin solution $(0.1 \%, \mathrm{w} / \mathrm{v}$, in distilled water); and $0.5 \mathrm{~g}$ cysteine. $\mathrm{HCl}$. The medium was boiled and cooled to room temperature under a stream of $\mathrm{O}_{2}$-free $\mathrm{N}_{2}$. The $\mathrm{pH}$ of the medium was adjusted to 7.0 with $10 \mathrm{M} \mathrm{NaOH}$. It was then distributed anaerobically as $20 \mathrm{ml}$ aliquots in $65 \mathrm{ml}$ capacity serum vials which were sealed with butyl rubber stoppers and crimped with aluminium seals. Sterilization was carried out by autoclaving at $121^{\circ} \mathrm{C}$ for $20 \mathrm{~min}$. The vials were then fortified with sterile groundnut oil emulsion, prepared as described above, to have final oil concentration of $1 \%$ $(\mathrm{w} / \mathrm{v})$.

PY medium (peptone/yeast extract medium) of the following composition $\left(1^{-1}\right)$ was prepared (Holdeman et al., 1977): $10 \mathrm{~g}$ peptone; $10 \mathrm{~g}$ yeast extract ; $40 \mathrm{ml}$ salt solution; $1 \mathrm{ml}$ resazurin solution $(0 \cdot 1 \%, \mathrm{w} / \mathrm{v}$, in distilled water $)$; and $0.5 \mathrm{~g}$ cysteine. $\mathrm{HCl}$. Composition of the salt solution (100$\mathrm{ml}^{-1}$ ) was as follows: $0.1 \mathrm{~g} \mathrm{~K}_{2} \mathrm{HPO}_{4} ; 0.1 \mathrm{~g} \mathrm{KH}_{2} \mathrm{PO}_{4} ; 1.0 \mathrm{~g}$ $\mathrm{NaHCO}_{3} ; 0.2 \mathrm{~g} \mathrm{NaCl} ; 0.02 \mathrm{~g} \mathrm{CaCl}_{2}$ anhydrous; and $0.02 \mathrm{~g}$ $\mathrm{MgSO}_{4} .7 \mathrm{H}_{2} \mathrm{O}$. The medium was boiled and cooled to room temperature under a stream of $\mathrm{O}_{2}$-free $\mathrm{N}_{2}$. The $\mathrm{pH}$ of the medium was adjusted to 7.0 with $10 \mathrm{M} \mathrm{NaOH}$ solution. It was then distributed anaerobically and sealed using butyl rubber stoppers and aluminium seals. PYG medium (peptone/yeast extract/glucose medium) was prepared by adding $10 \mathrm{~g}$ glucose per litre of the PY medium.

All experiments using the solid media were performed in an anaerobic glove box (Forma Scientific). The solid media were prepared using agar/agar as the solidifying agent at a concentration of $30 \mathrm{~g} \mathrm{I}^{-1}$ and poured into glass Petri plates inside the anaerobic glove box.

Unless mentioned otherwise, the incubation temperature was $35^{\circ} \mathrm{C}$.

Isolation and purity. As direct isolation failed to yield bacterial growth on solid medium, enrichment was set up by inoculating the sample $(10 \%, \mathrm{v} / \mathrm{v})$ in the OA-1 medium containing $1 \%(\mathrm{w} / \mathrm{v})$ groundnut oil. The enriched sample was streaked onto the OA-1 agar containing $1 \%(\mathrm{w} / \mathrm{v})$ triolein. After the incubation period of $5 \mathrm{~d}$, the colonies showing a clearance zone were subcultured and their purity and lipolytic activity were confirmed. The purity of the isolate was confirmed by the streak-plate method using PYG agar plates and the serially diluted culture. The characteristics of all the colonies obtained in this manner were identical. Furthermore, randomly selected colonies obtained from different dilutions showed rod-shaped, Gram-negative bacteria that had identical morphological characteristics by microscopic examination. The subculture of each colony showed a clearance zone on triolein agar plates, confirming the purity and lipolytic ability of the isolated culture.

Cellular characterization. Gram-staining characteristics were determined with a standard Gram-stain kit (Hi Media). Presence or absence of spore formation in the culture was examined by phase-contrast microscopy (Nikon) at the end of growth in different media including PY, PYG, OA-1 and Robinson's cooked meat medium (Hi Media). The broth culture in PYG medium was heated in a water bath at $85^{\circ} \mathrm{C}$ for $2 \mathrm{~h}$ and then stored at $4^{\circ} \mathrm{C}$ for $4 \mathrm{~h}$ to check whether heat shocks could stimulate spore formation. Motility was determined under the phase-contrast microscope by making observations of wet mounts of the broth culture using a glass cavity slide. After putting the cover-slip on the culture drop, the edges of the cover-slip were immediately sealed by molten wax. This helped to keep the culture active for 
Table 1. Comparative characteristics of strain $\mathrm{CF} 1 \mathrm{~B}^{\top}$ with other closely related anaerobes from the family Bacteroidaceae

Information obtained from Hespell et al. (1992); Holdeman et al. (1984); Lee et al. (1978); and Schauder \& Schink (1989) except for strain $\mathrm{CF} 1 \mathrm{~B}^{\mathrm{T}}$. N, Data not available; v, variable.

\begin{tabular}{|c|c|c|c|c|}
\hline Characteristic & $\begin{array}{l}\text { S. ruminantium subsp. } \\
\text { lactilytica }\end{array}$ & CFIB $^{\mathrm{T}}$ & P. cerevisiphilus & A. lipolytica \\
\hline Habitat & Rumen & Tropical anaerobic lagoon & Spoiled packaged beer & Rumen \\
\hline Morphology & Curved rods & Curved rods & Slightly curved rods & Curved rods \\
\hline Size $(\mu \mathrm{m})$ & $0 \cdot 9-1 \cdot 1$ by $3-6$ & $0.55-0.77$ by $3.3-4.5$ & $0.7-0.8$ by $2-32$ & 0.5 by $1.2-3.6$ \\
\hline Gram staining & Gram-negative & Gram-negative & Gram-negative & Gram-negative \\
\hline Sporulation & Non-spore-forming & Non-spore-forming & Non-spore-forming & Non-spore-forming \\
\hline Flagellar arrangement & $\begin{array}{l}\text { Linear arrangement as a } \\
\text { tuft near the centre of the } \\
\text { concave side }\end{array}$ & $\begin{array}{l}\text { Linear arrangement as a } \\
\text { tuft near the centre of the } \\
\text { concave side }\end{array}$ & $\begin{array}{l}\text { Attached only on the } \\
\text { concave side but not } \\
\text { limited to the central } \\
\text { portion }\end{array}$ & Single polar flagellum \\
\hline \multicolumn{5}{|l|}{ Growth temperature: } \\
\hline Optimum temperature $\left({ }^{\circ} \mathrm{C}\right)$ & 37 & 40 & 32 & \\
\hline Temperature range & Does not grow below $20-30^{\circ} \mathrm{C}$ & $30-47^{\circ} \mathrm{C}$ & $15-40^{\circ} \mathrm{C}$ & $\begin{array}{l}\text { Growth occurs at } 38^{\circ} \mathrm{C} \\
\text { but not at } 20,30 \text { or } 50^{\circ} \mathrm{C}\end{array}$ \\
\hline $\begin{array}{l}\text { End-products of glucose } \\
\text { fermentation }\end{array}$ & Acetate and propionate & Acetate and propionate & Acetate and propionate & Does not utilize glucose \\
\hline $\begin{array}{l}\text { Requirement of } n \text {-valerate for } \\
\text { glucose utilization }\end{array}$ & Required & Not required & Not required & - \\
\hline DNA G $+\mathrm{C}$ content $(\mathrm{mol} \%)$ & $48-60$ & 40 & 39.8 & $31 \cdot 4$ \\
\hline \multicolumn{5}{|l|}{ Utilization of carbon sources: } \\
\hline Lactate & + & - & + & + \\
\hline Cellobiose & + & + & + & - \\
\hline Mannitol & + & - & + & - \\
\hline Sucrose & + & + & - & - \\
\hline Galactose & + & + & + & - \\
\hline Lactose & + & + & - & - \\
\hline Glucose & + & t & + & - \\
\hline Mannose & $\mathrm{v}$ & + & + & - \\
\hline Arabinose & + & + & + & - \\
\hline Maltose & + & + & + & - \\
\hline Inositol & $\mathrm{v}$ & + & - & - \\
\hline Dulcitol & + & - & + & - \\
\hline Inulin & $\mathrm{v}$ & + & - & - \\
\hline Salicin & + & + & - & - \\
\hline Starch & $\mathrm{v}$ & + & - & - \\
\hline Aesculin & + & + & - & - \\
\hline Raffinose & + & + & - & - \\
\hline Rhamnose & $\mathrm{N}$ & - & + & $\mathrm{N}$ \\
\hline Melibiose & + & + & - & $\mathrm{N}$ \\
\hline Melizitose & $\mathrm{N}$ & + & - & $\mathrm{N}$ \\
\hline
\end{tabular}

$7-8$ min due to the presence of reductant in the medium which helped in temporarily maintaining anaerobiosis.

Growth and metabolic properties. The ability of the isolate to grow under aerobic and obligately anaerobic conditions was tested using the PYG agar plates and the PYG broth. The catalase, indole and gelatin-liquefaction tests were performed according to the methods of Holdeman et al. (1977). The proteolysis was tested on milk agar plates (Hi Media); a clearance zone was taken as a positive result.

Determination of optimum $\mathrm{pH}$ and temperature. PYG medium was used to determine growth of the isolate at different $\mathrm{pH}$ and temperature values. A cell suspension was prepared by suspending cell growth from PYG agar plate in sterile anaerobic saline of $\mathrm{pH} 7.0$ and used as the inoculum $(10 \%, v / v)$. The optical density $\left(\mathrm{OD}_{600}\right)$ of the cell suspension, determined using a Bausch \& Lomb spectrophotometer, was $0 \cdot 3$.

Requirement for $\mathrm{NaCl}$. PYG broth $(\mathrm{pH} \mathrm{7.0)}$ was prepared with varying concentrations of $\mathrm{NaCl}\left(0-100 \mathrm{~g} \mathrm{l}^{-1}\right)$. The vials were inoculated with the well-grown culture in PYG $(10 \%$, $\mathrm{v} / \mathrm{v}$ ) and incubated for $5 \mathrm{~d}$. At the end of the incubation period, the culture broth was analysed for volatile fatty acid content.

Utilization of carbon source. The test was performed in anaerobic vials containing $18 \mathrm{ml}$ PY broth plus the respective test substrate (Table 1), added to give final concentration of $1 \%(\mathrm{w} / \mathrm{v})$. A vial containing PY broth without any addition of substrate served as the control. The culture grown in PYG was used as the inoculum $(10 \%, \mathrm{v} / \mathrm{v})$. All the inoculated vials were incubated for a period of $4 \mathrm{~d}$. At the end of the incubation period, the $\mathrm{pH}$ of each vial was measured and only those vials which showed a $\mathrm{pH}$ drop by a value greater than 0.5 units over the control vial were taken as positive, indicating that the test compound was utilized (Holdeman et al., 1984). It is worthwhile to mention that growth of the isolate in the plain PY broth resulted in a drop in $\mathrm{pH}$ by only $0 \cdot 2$ units.

Utilization of nitrogen source. The ability of the isolate to use different nitrogenous compounds as nitrogen source was tested on agar plates. To test the utilization of nitrogen sources, peptone and yeast extract were excluded from the PYG medium. To achieve desired anaerobiosis in this medium, cysteine. $\mathrm{HCl}$ was added as the reducing agent at a 
concentration of $0.5 \mathrm{~g} \mathrm{l}^{-1}$. The PYG agar modified in this manner served as the control medium. The modified PYG agar thus contained glucose, reductant, salt solution, resazurin and agar/agar. The test compounds were added separately at a concentration of $0.5 \%(\mathrm{w} / \mathrm{v})$. The culture grown on PYG agar was streaked onto the test and control media. The agar plates were incubated for $5 \mathrm{~d}$. Growth of the isolate during three successive transfers on the medium containing the specific nitrogen source was taken as a positive result. The control medium showed poor growth of the isolate; this could be due to the presence of cysteine at a very low concentration.

Requirement for $n$-valerate. The test was carried out in Hungate tubes containing PYG medium with $\left(500 \mathrm{mg} \mathrm{l}^{-1}\right)$ and without n-valerate supplementation. Growth curves were plotted by taking $\mathrm{OD}_{600}$ at regular time intervals. At the end of the incubation, the culture broth was analysed for volatile fatty acid content.

Antibiotic sensitivity pattern. Sensitivity of the culture towards different antibiotics was checked by disk assay using standard antibiotic disks (Hi Media). The culture grown in OA-1 medium containing $1 \%(\mathrm{w} / \mathrm{v})$ emulsified tributyrin was spread on agar plates prepared using the same medium. The antibiotic disk was placed at the centre of each plate. The plates were incubated for $5 \mathrm{~d}$ and the zone of inhibition of growth around the antibiotic disk was measured. Referring to the manufacturer's protocol, the response of the culture towards different antibiotics was classified as resistant, intermediate and sensitive depending upon the diameter of the inhibition zone.

Determination of $\mathbf{G}+\mathbf{C}$ content of the DNA. The DNA was isolated by the method of Marmur (1961) with a modification in the method for lysis of the cells. The cells were lysed using $10 \%(\mathrm{v} / \mathrm{v})$ Triton X-100 in Tris/EDTA buffer of $\mathrm{pH} 8 \cdot 0$. The $\mathrm{G}+\mathrm{C}$ content was determined by the thermal denaturation $\left(T_{\mathrm{m}}\right)$ method (Mandel \& Marmur, 1968), using a spectrophotometer (DU-8B; Beckman) with a thermal programming facility.

Plasmid isolation was carried out by the alkaline lysis method (Birnboim \& Doly, 1979).

165 rDNA sequence analysis. The DNA was extracted from $3 \mathrm{ml}$ culture. Amplification of 16S rRNA gene was carried out using PCR (Perkin Elmer) as described by Moore et al. (1993). Conserved priming sites were used for the amplification. This gave a fragment of around $1.5 \mathrm{~kb}$ which was then purified by filtration on Microcon 100 columns to remove unincorporated primers and dNTPs. The concentration of purified PCR product was checked on an agarose gel.

The purified product was sequenced directly by Gibco-BRL ds Cycle Sequencing kit using the manufacturer's protocol. The gel was run on IBI-Kodak Base Runner 100 and an electrolyte gradient was used to enable reading of longer sequences (Ausubel, 1995). Using a single primer that binds to position 8-27 (Escherichia coli numbering), the sequence of 250 bases at the $5^{\prime}$ end of the molecule was determined. The primer used was F27 and had the following sequence: AGAGTTTGATC(A/C)TGGCTCAG. This region was selected for the analysis because it includes the hypervariable region V2. An additional sequence at the $3^{\prime}$ end was also determined. Here, the primer used was R1525-XP, which had the sequence TTCTGCAGTCTAGAAGGAGGTG(T/A)TCCAGCC. The sequence was read manually and analysis was done at the RDP (Ribosomal Database Project)
(Maidak et al., 1996). The analysis gave a partial 16S rRNA sequence ( 250 bases) of isolate CF1 B ${ }^{\mathrm{T}}$ (GenBank accession no. AF001901).

The alignment, similarity and distance estimations were done using CLUSTAL v (Higgins et al., 1992). The $S_{a b}$ values were obtained by similarity check program at RDP. To determine the correct extent of sequence similarity between strain $\mathrm{CF}_{1 \mathrm{~B}^{\mathrm{T}}}$ and other closely related organisms, all available sequences of species of the genera Selenomonas and Pectinatus were retrieved from the database. The sequence of strain CFlB ${ }^{\mathrm{T}}$ was then aligned with these sequences using CLUSTAL $\mathrm{V}$. These aligned sequences were then used to determine the similarity values and distance. The phylogenetic tree was constructed using distance values.

Lipolytic activity. Agar plates of OA-1 medium were used for qualitative plate clearance assays. Tributyrin, triolein and refined groundnut oil were used individually to check the lipase activity. The substrate stocks were prepared as described above. The substrates were sterilized separately and added to the molten agar medium. The culture grown in OA-1 medium containing $1 \%(\mathrm{w} / \mathrm{v})$ groundnut oil was spotinoculated on the plates. The clearance zone from the centre of the colony was measured after incubation for $5 \mathrm{~d}$. Results were confirmed by giving successive transfers on the same substrate.

Analytical techniques. Volatile fatty acids in the broth cultures were analysed by GC ( 8510 ; Chemito) equipped with a flame ionization detector (oven temperature $150^{\circ} \mathrm{C}$, injector temperature $170^{\circ} \mathrm{C}$, detector temperature $190^{\circ} \mathrm{C}$ ). The column used was Chromosorb W(HP) $(1.83 \mathrm{~m} \times$ $3.2 \mathrm{~mm}, \mathrm{SS}$ ) packed with $10 \%$ FFAP and $2 \% \mathrm{H}_{3} \mathrm{PO}_{4}$. The carrier gas used was $\mathrm{N}_{2}$ at the flow rate of $30 \mathrm{ml} \mathrm{min}-1$.

Lactic acid was estimated after esterification of the sample using the same $\mathrm{GC}$ with a flame ionization detector (oven temperature $110^{\circ} \mathrm{C}$, injector temperature $150^{\circ} \mathrm{C}$, detector temperature $190^{\circ} \mathrm{C}$ ). The esters were prepared by adding $1 \mathrm{ml}$ of the sample to $2 \mathrm{ml} 15 \%(\mathrm{v} / \mathrm{v}) \mathrm{H}_{2} \mathrm{SO}_{4}$ in methanol. The reaction mixture was kept in a boiling water bath for $3 \mathrm{~h}$. Esters were extracted by adding $1 \mathrm{ml}$ chloroform. The chloroform layer was used for $\mathrm{GC}$ analysis. A fused silica capillary column, BP-1 $(25 \mathrm{~m} \times 0.32 \mathrm{~mm})$, was used. The carrier gas used was $\mathrm{H}_{2}$ at the split ratio of $30: 1$.

$\mathrm{H}_{2} \mathrm{~S}$ was detected using a GC ( 3800 ; Chemito) equipped with a thermal conductivity detector (oven temperature $75^{\circ} \mathrm{C}$, injector temperature $90^{\circ} \mathrm{C}$, detector temperature $90^{\circ} \mathrm{C}$ ). The column used was Porapak Q $(1.83 \mathrm{~m} \times 3.2 \mathrm{~mm}, \mathrm{SS})$. The carrier gas used was $\mathrm{H}_{2}$ at the flow rate of $25 \mathrm{ml} \mathrm{min}^{-1}$.

In all the GC analyses, data analysis was done using an integrator (SP 4270; Spectra Physics). All experiments were done in duplicate.

\section{RESULTS}

\section{Isolation}

One pure culture of an obligately anaerobic bacterium showing a degradation zone on tributyrin, triolein and groundnut oil was obtained from the enrichment bottle, which was set up using the sample of semi-solid sediment from an anaerobic lagoon and OA-1 medium containing $1 \%(\mathrm{w} / \mathrm{v})$ groundnut oil. The culture was designated $\mathrm{CF} 1 \mathrm{~B}^{\mathrm{T}}$ and characterized further. The 


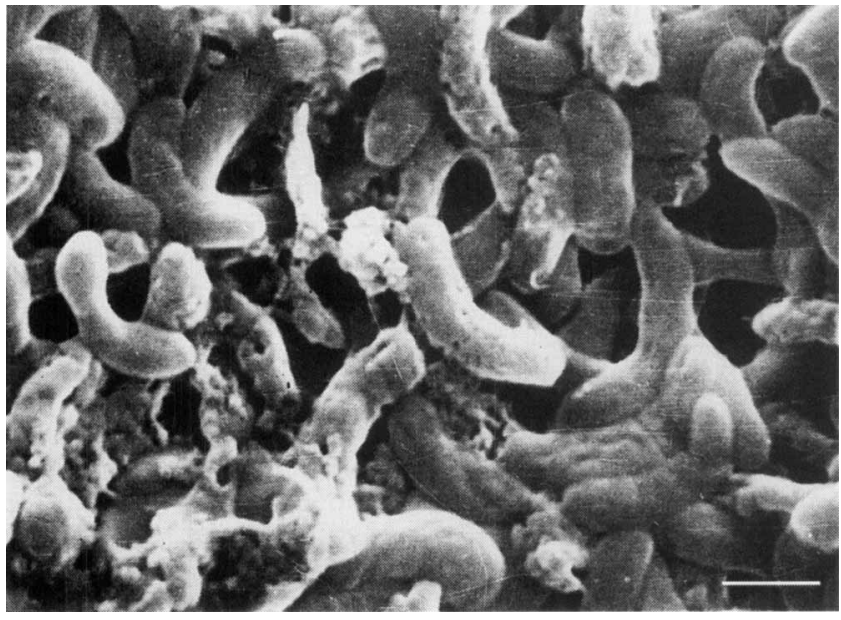

Fig. 1. Scanning electron micrograph of strain $\mathrm{CF} \mathrm{B}^{\top}$. Cells from an exponentially growing culture were fixed using $2 \%(\mathrm{w} / \mathrm{v})$ glutaraldehyde solution for $12 \mathrm{~h}$. The cells were then dehydrated by gradual washing with an increasing grade of ethanol by a standard method. The sample was allowed to air dry. The gold coating ( $20 \mathrm{~nm}$ thick) of the sample was done using an E 5200 Auto Sputter Coater (Bio-Rad). The observations were made on a Stereoscan S 120 scanning electron microscope (Cambridge Instruments). Bar, 1.16 $\mu \mathrm{m}$.

colonies of this organism on PYG agar were light brown, spherical, $2 \mathrm{~mm}$ in diameter, opaque, convex and had defined borders. The fully grown colonies possessed a more dense and elevated pointed centre. The bacterium showed confluent mat growth on tributyrin agar but not on PYG agar.

\section{Cellular properties}

Cells of the strain $\mathrm{CF} 1 \mathrm{~B}^{\mathrm{T}}$ were typical curved rods measuring $0.55-0.77$ by $3.3-4.5 \mu \mathrm{m}$ in size and occurred singly (Fig. 1). When the culture was stained with safranin, central large granules were prominently seen under oil emulsion (magnification $\times 1000$ ). The strain was Gram-negative, non-spore-forming and actively motile. The motility was very poor in PYG broth, but was markedly enhanced when the cells were grown in glycerol- and phosphate-containing medium. Transmission electron microscopy revealed the presence of 4-5 flagella, arranged linearly as a tuft near the centre of the concave side (Fig. 2).

\section{Growth and metabolic properties}

The strain could not grow on the PYG agar plates as well as in the PYG broth under aerobic conditions. Similarly, it failed to grow if the reducing agent, namely cysteine. $\mathrm{HCl}$, was removed from the medium. These results confirmed that the strain was obligately anaerobic. It was catalase-negative and indole-negative. Strain $C F 1 B^{T}$ could not hydrolyse gelatin, but showed proteolytic activity on milk agar. Acetate and propionate were the only volatile fatty acids produced from glucose fermentation with production of carbon

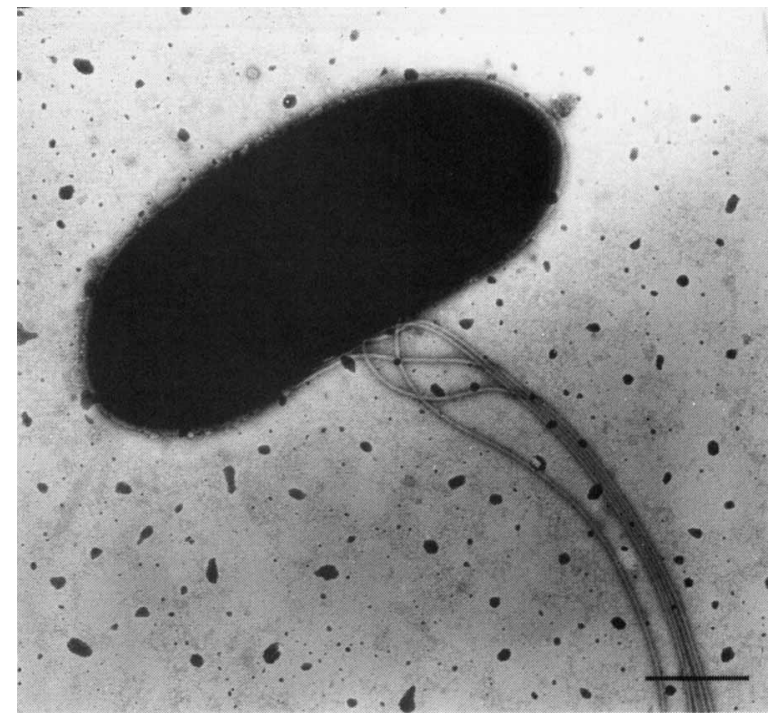

Fig. 2. Transmission electron micrograph of strain CF1B ${ }^{\top}$. Cells were harvested from an actively growing culture and fixed in $1 \%(\mathrm{w} / \mathrm{v})$ glutaraldehyde in $0.2 \mathrm{M}$ sodium cacodylate buffer at $\mathrm{pH} 7.2$ for $10 \mathrm{~min}$ at $4{ }^{\circ} \mathrm{C}$. The cells were then washed with one change of the cacodylate buffer and negatively stained with $1 \%(w / v)$ potassium phosphotungstic acid solution by direct ongrid staining. Electron microscopy was done using a Philips EM 301 transmission electron microscope. The samples were seen under $80 \mathrm{kV}$ operating voltage in a standard fixed highresolution stage and photographed on Kodak 4489 thick-base EM film (Eastman Kodak). Bar, $400 \mathrm{~nm}$.

dioxide and propionate as the major end product. Strain $C F 1 B^{\mathrm{T}}$ did not require n-valerate when grown on glucose, which was evident from the growth curves plotted using the medium with and without n-valerate supplementation (data not shown). It produced almost equal amounts of volatile fatty acid in the presence and absence of n-valerate and also, the added n-valerate remained unutilized in the test. The optimum temperature for growth was $40{ }^{\circ} \mathrm{C}$ and growth occurred at temperatures of $30-47^{\circ} \mathrm{C}$ (Fig. 3). The culture showed growth over a $\mathrm{pH}$ range of $5 \cdot 0-7 \cdot 4$ with maximum growth at $\mathrm{pH} 6.8$ (Fig. 3). The strain could tolerate an $\mathrm{NaCl}$ concentration of up to $40 \mathrm{~g} \mathrm{l}^{-1}$, but optimum growth of the strain occurred in the absence of $\mathrm{NaCl}$ in the PYG medium. This was evident from maximum volatile fatty acid production in the absence of $\mathrm{NaCl}$ in the PYG broth. The absence of both growth and volatile fatty acid production clearly indicated that the strain could not tolerate $\mathrm{NaCl}$ concentrations greater than $40 \mathrm{~g} \mathrm{l}^{-1}$.

Fermentable substrates included cellobiose, sucrose, galactose, lactose, glucose, mannose, arabinose, maltose, inositol, inulin, salicin, starch, aesculin, raffinose, melibiose, melizitose and glycerol (Table 1). The following compounds were not utilized as sole carbon and energy source: mannitol, xylose, sorbose, rhamnose, dulcitol, sorbitol or DL-lactate. The utilization of lactate was checked by estimating the concentration of DL-lactate from the culture broth using GC. It was 

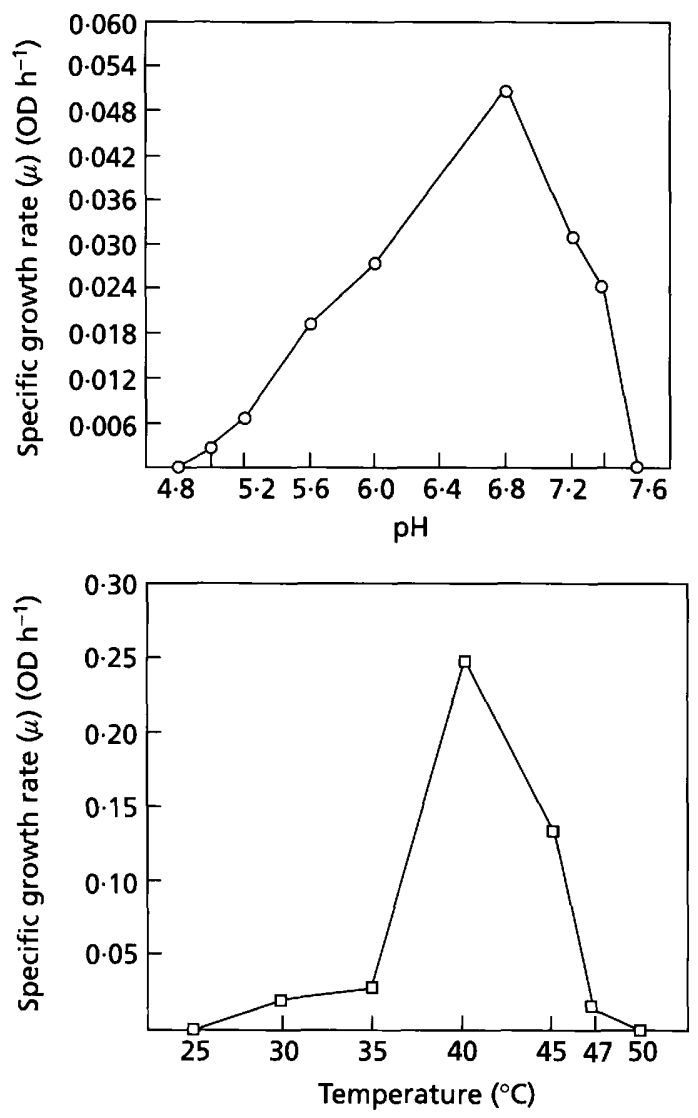

Fig. 3. Effect of initial pH and temperature on growth.

clearly seen that the lactate remained totally unutilized in the inoculated vials.

Strain $\mathrm{CF}_{1 \mathrm{~B}^{\mathrm{T}}}$ could utilize $\mathrm{NH}_{4} \mathrm{Cl}, \mathrm{KNO}_{3}$, L-cysteine, histidine, serine and aspartate as sole nitrogen source. It produced $\mathrm{H}_{2} \mathrm{~S}$ from L-cysteine.

\section{Antibiotic sensitivity pattern}

The strain was resistant to gentamicin, amikacin, neomycin, tobramycin, kanamycin, streptomycin, erythromycin, sisomycin, trimethoprim, co-trimoxazole, sulphaphenazole, cloxacillin, norfloxacin, novobiocin and rifampicin. The strain showed an intermediate response to cephotaxime, ofloxacin, ciprofloxacin and nalidixic acid. It was sensitive to chloramphenicol, tetracycline, chlortetracycline, metronidazole, nitrofurantoin, amoxycillin, ampicillin, carbenicillin, cephaloridine, penicillin, cephazolin and cephalexin. Thus, the strain showed a considerable resistance to antibacterial compounds that affecting protein synthesis, but it was sensitive to most of the antibiotics that affect cell-wall synthesis.

\section{DNA base composition}

The mean DNA G + C composition, as determined by $T_{\mathrm{m}}$ analysis, was $40 \mathrm{~mol} \%$. The strain did not contain any plasmid.

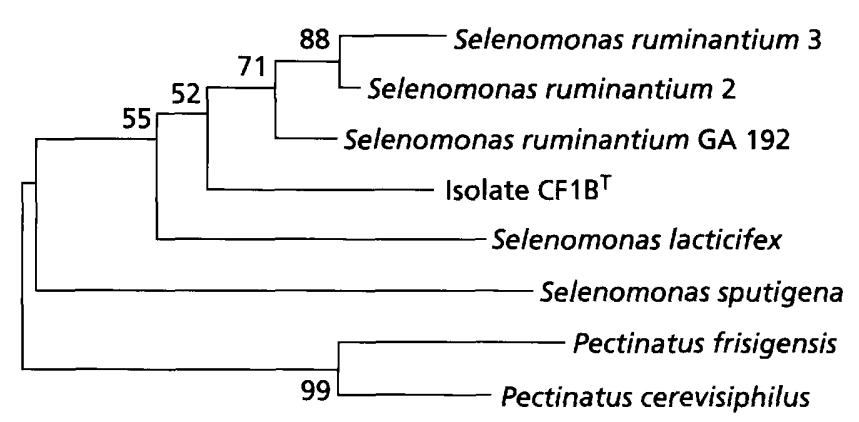

Fig. 4. Unrooted phylogenetic tree derived from the distance values (data not shown). The neighbour-joining method was used for generation of the tree. The numbers at the branches indicate the bootstrap values (percentages) after 1000 replications.

\section{S rDNA sequence analysis}

The partial $16 \mathrm{~S}$ rDNA sequence of strain $\mathrm{CF} 1 \mathrm{~B}^{\mathrm{T}}$ (250 bp) was compared with those available in the RDP. The estimated $S_{a b}$ values for the partial 16S rDNA sequence of the isolate CF1 $\mathbf{B}^{\mathrm{T}}$ with different species of the genera Selenomonas and Pectinatus were as follows: Selenomonas ruminantium strain GA 192, $0.674 ; S$. ruminantium strain HD4, 0.661; S. ruminantium subsp. lactilytica, $0 \cdot 552$; Selenomonas lacticifex, 0.448; Selenomonas sputigena, 0.310; Pectinatus cerevisiphilus, 0.305; and Pectinatus frisigensis, 0.259. The results clearly indicated that isolate $C F 1 B^{T}$ was most closely related to $S$. ruminantium strain GA 192 with a maximum $S_{a b}$ value of $0 \cdot 674$. Furthermore, the isolate showed maximum similarity of $91 \%$ with $S$. ruminantium strain GA 192 , followed by $89 \%$ with other strains of $S$. ruminantium. Different strains of $S$. ruminantium had the similarity of minimum $95 \%$. The similarity values of the strain $\mathrm{CF} 1 \mathrm{~B}^{\mathrm{T}}$ with other species of Selenomonas were $79-90 \%$ and those with the species of the genus Pectinatus were below $80 \%$. Even when the analysis included all the organisms for which sequences are available at RDP, the isolate showed highest similarity with only $S$. ruminantium.

The phylogenetic tree constructed using the distance values grouped this isolate with the genus Selenomonas but it was distinct from S. ruminantium (Fig. 4).

\section{Lipolytic activity}

Strain CF1 $\mathrm{B}^{\mathrm{T}}$ possessed true lipolytic activity. It could hydrolyse tributyrin, triolein and groundnut oil to show prominent clearance zones in qualitative plate clearance assays (Fig. 5). It was observed that tributyrin and triolein were hydrolysed even when emulsified in plain distilled water. Groundnut oil was completely hydrolysed only when it was emulsified in $2 \%(\mathrm{w} / \mathrm{v})$ polyvinyl alcohol solution in distilled water. The presence or absence of trace element solution did not have any effect on lipolytic activity of the culture when tributyrin and triolein were used as the substrates. The presence of the trace element solution had 


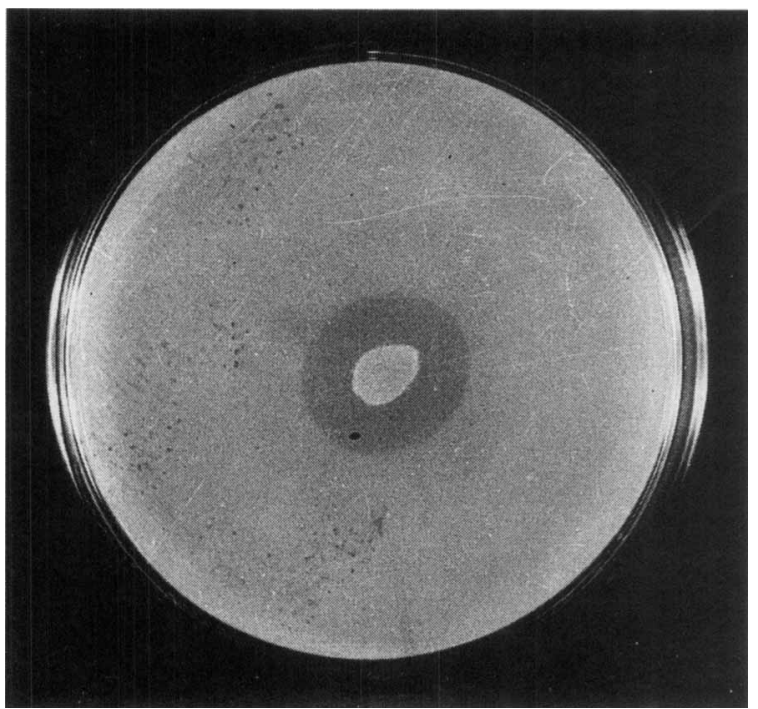

Fig. 5. Strain $\mathrm{CF}_{1} \mathrm{~B}^{\top}$ showing degradation zone on triolein agar plate.

a markedly positive effect when groundnut oil was used as the substrate.

\section{DISCUSSION}

On the basis of different cellular and physiological characteristics, strain $C F 1 B^{T}$ was classified as a species belonging to the family Bacteroidaceae. It shared some characteristics, including the ability to ferment glycerol, with three different genera of the family Bacteroidaceae, namely, Selenomonas, Anaerovibrio and Pectinatus. Table 1 shows the comparative characteristics of these organisms with the isolated strain $\mathrm{CF} 1 \mathrm{~B}^{\mathrm{T}}$. Among these three genera, only Anaerovibrio has been reported to possess lipolytic activity in the species A. lipolytica (Hungate, 1966). Other major characteristics of strain CF1 $\mathrm{B}^{\mathrm{T}}$, however, were significantly different to those of Anaerovibrio, particularly $\mathrm{G}+\mathrm{C}$ content of the DNA, flagellar arrangement and utilization of different substrates for growth. The strain, therefore, could not be classified as a species of Anaerovibrio.

The strain resembled Pectinatus with respect to some characteristics like morphology, volatile fatty acid produced after glucose fermentation and $\mathrm{G}+\mathrm{C}$ content of the DNA. The strain showed a higher optimum temperature for growth than Pectinatus. A striking difference was observed in flagellar arrangement. Strain CF $1 B^{\mathrm{T}}$ showed a tuft of flagella near the centre of the concave side, which is a peculiar characteristic of the genus Selenomonas (Holdeman et al., 1984; Kingsley \& Hoeniger, 1973). In the case of Pectinatus, the flagella are typically located all over the surface of the concave side and never occur as a tuft (Holdeman et al., 1984; Lee et al., 1978). Moreover, the isolated strain showed true lipolytic activity. There is not a single strain of genus Pectinatus that is reported to possess lipolytic activity (Holdeman et al., 1984; Haikara, 1992). The 16S rDNA sequence analysis showed that strain $\mathrm{CF} 1 \mathrm{~B}^{\mathrm{T}}$ shared only $77.4 \%$ sequence similarity with $P$. cerevisiphilus and $76 \%$ sequence similarity with $P$. frisigensis. These findings confirmed that the strain $\mathrm{CF} 1 \mathrm{~B}^{\mathrm{T}}$ did not belong to the genus Pectinatus.

The strain showed striking morphological similarity, including the flagellar arrangement, with the genus Selenomonas. Excess glucose in the nutrient medium causes loss of flagella in Selenomonas (Kingsley \& Hoeniger, 1973). Similar results were observed for the isolated strain. Addition of phosphate and glycerol to the growth medium enhanced the motility of strain $\mathrm{CF} 1 \mathrm{~B}^{\mathrm{T}}$. This again is a typical characteristic of the genus Selenomonas (Holdeman et al., 1984). The strain also showed greater resemblance to the genus Selenomonas with respect to the spectrum of utilization of carbon sources and temperature requirement for growth. Like Selenomonas, the strain produced acetate and propionate as the end products of glucose fermentation, with propionate as the major end product. The strain also resembled the genus Selenomonas with respect to production of $\mathrm{H}_{2} \mathrm{~S}$ from $\mathrm{L}$-cysteine.

The 16S rDNA sequence analysis showed that strain CF $1 \mathrm{~B}^{\mathrm{T}}$ was closely related to genus Selenomonas with $91 \%$ sequence similarity over the 250 bp sequence and an estimated $S_{a b}$ value of 0.674 for $S$. ruminantium strain GA 192. The isolated strain was resistant to most of the inhibitors of protein synthesis, including kanamycin $(30 \mu \mathrm{g}$ per disk). The isolate was highly sensitive to antibiotics like ampicillin $(10 \mu \mathrm{g}$ per disk) which affect cell-wall synthesis. S. ruminantium strain GA 192 has also been reported to be kanamycinresistant and ampicillin-sensitive (Ricke et al., 1996). No plasmids were detected in $S$. ruminantium strain GA 192 (Ricke et al., 1996). Similarly, strain CF1B ${ }^{\mathrm{T}}$ did not contain any plasmids.

Strain $\mathrm{CF} \mathrm{B}^{\mathrm{T}}$ did not require n-valerate supplementation for glucose utilization. S. ruminantium, with which the strain showed highest similarity, requires nvalerate for glucose utilization. The strain could utilize glycerol like $S$. ruminantium subsp. lactilytica. Increased utilization of lactate in presence of $p$-aminobenzoate and DL-aspartate is an important character of $S$. ruminantium subsp. lactilytica. Strain $C F 1 \mathbf{B}^{\mathrm{T}}$ could not utilize lactate even when the medium was supplemented with $p$-aminobenzoate and DL-aspartate. No species of the genus Selenomonas has been reported to possess lipolytic activity (Holdeman et al., 1984; Hespell et al., 1992). The strain CF1 ${ }^{\mathrm{T}}$ showed a strong and true lipolytic activity. The $\mathrm{G}+\mathrm{C}$ content of the DNA of the isolated strain was $40 \mathrm{~mol} \%$, whereas the $\mathrm{G}+\mathrm{C}$ content for the genus Selenomonas is reported to be $48-60 \mathrm{~mol} \%$.

Thus, the results clearly indicate that strain $\mathrm{CF} \mathrm{B}^{\mathrm{T}}$ is most closely related to the genus Selenomonas. At the same time, the strain shows some significant differences 
from the typical characteristics of the reported species of Selenomonas. Therefore, it could not be accommodated in the existing species of genus Selenomonas. Based on these findings, it is therefore proposed that a new species of the genus Selenomonas should be created to accommodate strain $\mathrm{CF} 1 \mathrm{~B}^{\mathrm{T}}$. The name Selenomonas lipolytica $\mathrm{sp}$. nov. is proposed for this isolate, with description given below.

\section{Description of Selenomonas lipolytica sp. nov.}

Selenomonas lipolytica (li.po.ly'ti.ca. Gr. n. lipos fat; Gr. adj. lytikos dissolving; M.L. adj. lipolytica fatdissolving).

Cells are curved rods, $0.55-0.77$ by $3.3-4.5 \mu \mathrm{m}$ in size and actively motile. Gram-negative, non-spore-forming, obligately anaerobic, catalase-negative, indolenegative. Strain $C F 1 B^{\mathrm{T}}$ cannot hydrolyse gelatin. The habitat is tropical anaerobic lagoon. The type strain is $\mathrm{CF} 1 \mathrm{~B}^{\mathrm{T}}$, which was isolated from a tropical anaerobic lagoon of an edible oil mill near Pune, India. Flagella (4-5) are arranged linearly as a single tuft near the centre of the concave side. Growth occurs at temperatures of $30-47^{\circ} \mathrm{C}$, with optimum growth occurring at $40^{\circ} \mathrm{C}$. The optimum $\mathrm{pH}$ is 6.8 . The strain could tolerate $\mathrm{NaCl}$ concentration up to $40 \mathrm{~g} \mathrm{l}^{-1}$ with optimum growth occurring in the absence of $\mathrm{NaCl}$ in PYG broth. The organism is sensitive to many antibiotics affecting cell-wall synthesis. It shows considerable resistance to antibacterial compounds affecting protein synthesis. It shows luxurious growth on glucose without any supplementation of $n$-valerate. Acetate and propionate are the only volatile fatty acids produced after fermentation of glucose, with propionate as the major end product. The strain shows strong and true lipolytic activity. It shows degradation zones on tributyrin, triolein and groundnut oil in qualitative plate clearance assays. The strain utilizes glycerol but not lactate. The $\mathrm{G}+\mathrm{C}$ content of the DNA is $40 \mathrm{~mol} \%$. The strain has maximum similarity with the genus Selenomonas with respect to a $16 \mathrm{~S}$ rDNA sequence with a similarity of $91 \%$ and $S_{a b}$ value of 0.674 for $S$. ruminantium strain GA 192.

The type strain, $\mathrm{CF} 1 \mathrm{~B}^{\mathrm{T}}$, has been deposited as MCMB $505^{\mathrm{T}}$, in the MCM culture collection centre (Maharashtra Association for Cultivation of Science Culture Collection of Microorganisms) established at Agharkar Research Institute, Pune, India.

\section{ACKNOWLEDGEMENTS}

We sincerely thank Dr P. N. Hobson (Aberdeen, UK) for valuable suggestions and information on the subject. We are grateful to Mr Atanu Basu of National Institute of Virology, Pune, for his help in transmission electron microscopy. Thanks are also due to Dr Mrs Vidya Gupta and Dr Mukund Deshpande, National Chemical Laboratory, Pune, for their help in analysis of $\mathrm{G}+\mathrm{C}$ content of the DNA. We acknowledge the help provided by Bioinformatics Centre, University of Pune, in the analysis of data. We thank Dr Sunil Rahalkar (Pune) and Ms Anita Kelkar (Pune) for helpful discussion and suggestions.

\section{REFERENCES}

Ausubel, F. M., Brent, R., Kingston, R. E., Moore, D. D., Seidman, J. G., Smith, J. A. \& Struhl, K. (1995). Current Protocols in Molecular Biology. New York: Wiley.

Birnboim, H. C. \& Doly, J. (1979). A rapid alkaline extraction procedure for screening recombinant plasmid DNA. Nucleic Acids Res 7, 1513-1523.

Cato, E. P., George, W. L. \& Finegold, S. M. (1986). Genus Clostridium Prazmowski 1880, 23 ${ }^{\mathrm{AL}}$. In Bergey's Manual of Systematic Bacteriology, vol. 2, pp. 1141-1200. Edited by P. H. A. Sneath, N. S. Mair, M. E. Sharpe \& J. G. Holt. Baltimore: Williams \& Wilkins.

Haikara, A. (1992). The genera Pectinatus and Megasphaera. In The Prokaryotes, vol. 2, pp. 1993-2004. Edited by A. Balows, H. G. Trüper, M. Dworkin, W. Harder \& K.-H. Schleifer. New York: Springer.

Henderson, C. (1971). A study of the lipase produced by Anaerovibrio lipolytica, a rumen bacterium. J Gen Microbiol 65 , 81-89.

Hespell, R. B., Paster, B. J. \& Dewhirst, F. E. (1992). The genus Selenomonas. In The Prokaryotes, vol. II, pp. 2005-2013. Edited by A. Balows, H. G. Trüper, M. Dworkin, W. Harder \& K.-H. Schleifer. New York: Springer.

Higgins, D. G., Bleasby, A. J. \& Fuchs, R. (1992). CluSTAL v, improved software for multiple sequence alignment. Comput Appl Biosci 8, 189-191.

Hobson, P. N. \& Mann, S. O. (1961). The isolation of glycerol fermenting and lipolytic bacteria from the rumen of the sheep. $J$ Gen Microbiol 25, 227-240.

Holdeman, L. V., Cato, E. P. \& Moore, W. E. C. (1977). Anaerobe Laboratory Manual, 4th edn. Blacksburg, VA: Virginia Polytechnic Institute \& State University Press.

Holdeman, L. V., Kelley, R. W. \& Moore, W. E. C. (1984). Family I. Bacteroidaceae Pribram 1933, 10 ${ }^{\mathrm{AL} *}$. In Bergey's Manual of Systematic Bacteriology, vol. 1, pp. 602-603. Edited by N. R. Krieg \& J. G. Holt. Baltimore: Williams \& Wilkins.

Hungate, R. E. (1966). The Rumen and its Microbes. London: Academic Press.

Hungate, R. E. (1969). A roll tube method for cultivation of strict anaerobes. Methods Microbiol 3B, 117-132.

Kingsley, V. V. \& Hoeniger, J. F. M. (1973). Growth, structure and classification of Selenomonas. Bacteriol Rev 37, 479-521.

Lee, S. Y., Mabee, M. S. \& Jangaard, N. O. (1978). Pectinatus, a new genus of the family Bacteroidaceae. Int J Syst Bacteriol 28, 582-594.

Maidak, B. L., Olsen, G. J., Larsen, N., Overbeek, R., McCaughey, M. J. \& Woese, C. R. (1996). The Ribosomal Database Project. Nucleic Acids Res 24, 82-85.

Mandel, M. \& Marmur, J. (1968). Use of ultraviolet absorbancetemperature profile for determining the guanine plus cytosine content of DNA. Methods Enzymol 12B, 195.

Marmur, J. (1961). A procedure for the isolation of deoxyribonucleic acid from microorganisms. $J$ Mol Biol 3, 208-218.

Miller, T. L. \& Wolin, M. J. (1974). A serum bottle modification of Hungate technique for cultivating obligate anaerobes. Appl Microbiol 27, 985-987.

Moore, E. R. B., Wittich, R. M., Fortnagel, P. \& Timmis, K. N. (1993). 16S ribosomal RNA gene sequence characterization and phylogeneric analysis of dibenzo- $p$-dioxin degrading isolate within the new genus Sphingomonas. Lett Appl Microbiol 17, $115-118$. 
Ricke, S. C., Martin, S. A. \& Nisbet, D. J. (1996). Ecology, metabolism and genetics of ruminal Selenomonads. Crit Rev Microbiol 22, 27-65.

Sarnaik, S., Godbole, S. H. \& Kanekar, P. (1989). Microbiological status of groundnut oil in Pune market. J Food Sci Technol 26, 337-340.

Schauder, R. \& Schink, B. (1989). Anaerovibrio glycerini sp. nov., an anaerobic bacterium fermenting glycerol to propionate, cell matter, and hydrogen. Arch Microbiol 152, 473-478.
Touzel, J. P. \& Albagnac, G. (1983). Isolation and characterization of Methanococcus mazei strain $\mathrm{MC}_{3}$. FEMS Microbiol Lett 16, 241-245.

Winteler, H. V., Schneidinger, B., Jaeger, K. E. \& Haas, D. (1996). Anaerobically controlled expression system derived from the arcDABC operon of Pseudomonas aeruginosa: application to lipase production. Appl Environ Microbiol 62, 3391-3398.

Wolin, E. A., Wolin, M. J. \& Wolfe, R. S. (1963). Formation of methane by bacterial extracts. $J$ Biol Chem 238, 2882-2886. 